S. Shilin, PhD,

varang77@ukr.net,

Z. Voitenko, Dr. Sci.

M. Nechai, stud.

Taras Shevchenko National University of Kyiv, Kyiv, Ukraine

\title{
SYNTHETIC PYRIDINE SUBSTITUTED AMINO ACIDS AND THEIR DERIVATIVES
}

This paper reports on the synthesis of new derivatives of $\varepsilon$-aminocaproic and $y$-aminobutyric acid modified with a pyridin-2-yl substituent at the $\omega$-position of the main chain.

The hemostatic activity of both $\varepsilon$-aminocaproic acid itself and its various synthetic analogues is widely known. Likewise, numerous $Y$ aminobutyric acid derivatives are strong neurotransmitters extensively used in the treatment of the nervous system disorders. No less popular are biologically active substances containing a pyridine or piperidine fragment; among which there are antibiotics, antimalarial, anti-sclerotic and antiallergic drugs, as well as anti-depressants and analgesics.

Therefore, the introduction of the pyridine fragment into the amino acid structures is interesting in terms of their potential biological activity investigation.

So, a method for the synthesis of 5-amino-5-(pyridin-2-yl)pentanoic and 6-amino-6-(pyridin-2-yl)hexanoic acid has been developed by us. The proposed scheme is based on the available reagents using. The key stage is the Schmidt rearrangement of 2-(pyridin-2-yl)cyclopentanone and 2(pyridin-2-yl)cyclohexanone, previously synthesized from pyridine $\mathbf{N}$-oxide and cycloalkenyl morpholinide. For synthesized pyridine substituted cycloalkanones according to NMR spectroscopy, the presence of keto-enol tautomerism was established.

As a result of Schmidt rearrangement, lactams (2-(pyridin-2-yl)piperidone and 2-(pyridin-2-yl)azepanone) are formed, and the last ones had been hydrolyzed in an acidic medium to open the lactam cycle. Thus, 5-amino-5-(pyridin-2-yl)pentanoic and 6-amino-6-(pyridin-2-yl)hexanoic acid were isolated as hydrochlorides and the hydrochlorides were converted to the zwitterion form using propylene oxide.

The first stage of the developed scheme (preparation of pyridylalkanones) occurs in rather low yields, about $35 \%$. But, after the rearrangement, hydrolysis and the formation of zwitterion do not cause difficulties and are characterized by high yields. Consequently, the proposed synthetic sequence is preparatively advantageous.

Keywords: synthetic $\delta$ - and $\varepsilon$-amino acids, Schmidt rearrangement, picolyl-2-amine.

УДК 547.586.5

DOI: https://doi.org/10.17721/1728-2209.2019.1(56).6

С. Шилін, канд. хім. наук,

О. Шабликіна, канд. хім. наук, shablykina@ukr.net,

Київський національний університет імені Тараса Шевченка, Київ, Україна

О. Шабликін, канд. хім. наук, Інститут біоорганічної хімії та нафтохімії ім. В. П. Кухаря НАН України, Київ, Україна В. Хиля, д-р хім. наук, чл.-кор. НАН України,

3. Нагорна, студ.

Київський національний університет імені Тараса Шевченка, Київ, Україна

\section{ОКРЕМІ ВИПАДКИ УТВОРЕННЯ О-АЛКОКСИКОРИЧНИХ КИСЛОТ НА ОСНОВІ КУМАРИНІВ В УМОВАХ О-АЛКІЛЮВАННЯ}

На основі різноманітних за будовою кумаринів шляхом розкриття лактонового фррагмента та О-алкілювання фенольного фрагмента отримано ряд нових похідних о-алкоксикоричних кислот. Дане перетворення для 3-азолілзаміщених кумаринів та фуро[3,2-g]кумаринів було здійснено у водному лужному середовищі, а для 7-гідрокси-4-метил-6-(ізокумарин-3іл)кумарину - при нагріванні в ДМСО в присутності поташу.

Ключові слова: кумарин, О-алкілювання, о-алкоксикорична кислота.

Історія розвитку хімії похідних кумарину налічує багато десятиліть і має чимало досягнень, які стосуються як природних сполук [1, 2], так і їхніх синтетичних аналогів [3-5]. Серед природних кумаринів є чимало алкоксипохідних, зокрема сполук із цінними біологічними характеристиками (рис. 1, речовини 1-3), тому не дивно, що реакція О-алкілювання часто $є$ однією зі стадій при створенні синтетичних кумаринів із практично корисними властивостями. Можна згадати, наприклад, нещодавно синтезовані кумарини із 1,2,3-тріазольним фрагментом 4, що виявили антибактеріальні та фрунгіцидні властивості [6], або естери по типу 5, що були використані для побудови складних фотолабільних молекул [7] (рис. 1).<smiles>COc1cc2c(cc1-c1cc3cc4ccoc4cc3oc1=O)OCO2</smiles>

пахиррізин

(Pachyrrhizus erosus, Neorautanenia pseudopachyrrhiza та ін.)<smiles>COc1cc(OC)c2c(OC)c(-c3ccc4c(c3)OCO4)c(=O)oc2c1</smiles>

2

дерруснін

(Derris robusta)<smiles>COc1ccc(-c2cc3c(OC)c(CC=C(C)C)c(OC)cc3oc2=O)c(OC)c1</smiles>

3

гліцирин

(Glycyrrhiza uralensis) антидіабетичні властивості<smiles>Cc1cc(=O)oc2cc(OCc3cn(C)nn3)c(OCc3ccccc3)cc12</smiles>

Рис. 1. Природні та синтетичні алкоксикумарини

Оскільки О-алкілювання проводиться переважно в присутності основи, то слід ураховувати чутливість лактонового фрагмента кумаринів, адже в лужному розчині ці бензопірони знаходяться в формі аніонів о-гідроксико- ричних кислот 6, френольна група яких також може зазнавати алкілювання. У такому випадку продуктом реакції буде корична кислота 7 із алкоксильною групою в о-положенні, що зображено загальною схемою на рис. 2. 


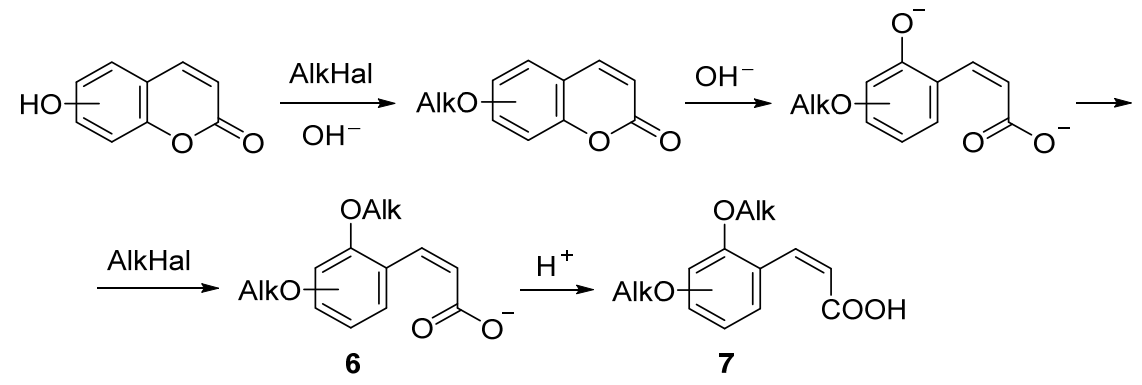

Рис. 2. Можливі продукти алкілювання гідроксикумарину в лужному середовищі

Літературних даних стосовно цього питання порівняно небагато і переважно вони стосуються сполук простої будови $[8,9]$, хоча в окремих випадках дана реакція фрігурує в схемах синтезу молекул із корисними властивостями. Так, унаслідок алкілювання в лужному середовищі кумарину 8, було отримано речовину 9 (рис. 3) [10], яку було використано в синтезі похідних 1,2,3-тріазолу 10 з протираковою активністю; а шляхом алкілювання речовини 8 у присутності $t$-BuOK було синтезовано естери загальної формули 11, які планувалось використовувати для лікування захворювань, пов'язаних із нейродегенеративними процесами [11] (рис. 3).<smiles>[R]n1cc(COc2c(/C=C/C(=O)O)ccc(OC)c2CC=C(C)C)nn1</smiles>

Рис. 3. Одержання практично значущих похідних о-алкоксикоричних кислот на основі кумаринів в умовах O-алкілювання (літературні дані)

Такі перетворення можуть набути більш широкого препаративного значення, оскільки отримані похідні коричних кислот здатні до подальшої модифікації за карбоксильною групою. 3 іншого боку, якщо метою $\epsilon$ алкілювання бічної групи, а розкриття кумаринового циклу небажане, то потрібно чітко розуміти межі стійкості лактону для вибору оптимальних умов проведення реакції. У даній роботі ми повідомляємо про окремі випадки розкриття кумаринового циклу в умовах О-алкілювання, що були нами зафіксовані в ході досліджень реакційної здатності різних за будовою кумаринів.

Раніше нами було синтезовано досить великий масив 3-(гет)арилкумаринів загальної фрормули 12 (рис. 4) та їх алкоксипохідних 13 [12-14], що цікавили нас передусім своїми спектральними характеристиками [15]. Перетворення $12 \rightarrow 13$ відбувалось у ацетоні (рідше - у ДМФА), переважно з високими виходами, і розкриття лактонової системи у жодному із випадків не було зафріксовано. Уточнимо, що цим кумарини 12 суттєво відрізняються від своїх 2-імінопохідних 14 (рис. 4), які в аналогічних умовах у реакціях із різноманітними алкілуючими агентами легко утворюють відповідні о-алкоксифенілакрилонітрили 15 [16]. За наявності в імінокумарині гідроксильної групи алкілювання її та ендоциклічного атома Оксигену відбувається практично одночасно.

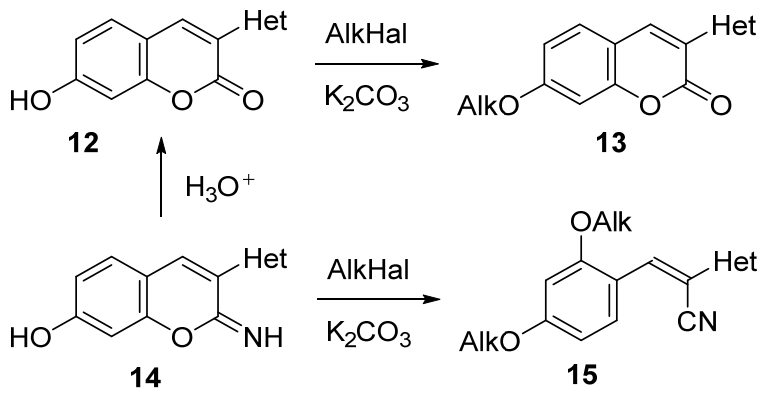

Рис. 4. 3-Гетарилкумарини та їх 2-імінопохідні в реакції Вільямсона

Для перевірки межі стійкості кумаринового фрагмента даного типу речовин ми провели алкілювання кумаринів 16a,b у лужному середовищі відповідно бензилхлоридом та диметилсульфатом (рис. 5). Попередньо вихідний кумарин було вміщено у 2,5\% водний розчин гідроксиду натрію в розрахунку на 3 екв. лугу; і лише після повного розчинення, що означає перехід речовини у відкриту аніонну форму 16', до реакційної суміші додавали алкілуючий засіб (див. розділ "Експериментальна частина"). У вказаних умовах речовину 16а з досить високим виходом було перетворено на бензилоксипохідну 17a; а у випадку алкілювання більш активним диметилсульфатом сполуки 16b (з більш основним гетероциклом) вихід цільового продукту 17b був помітно меншим через утворення значної кількості домішок.

Наступними об'єктами дослідження були фурокумарини 18a-d. Дані сполуки легко синтезувати з 7-гідрокси4-метилкумарину 19 за методом Робінсона [17-20], а саме: алкілюванням гідроксигрупи $\alpha$-галогенокетонами та наступним замиканням фуранового циклу в сильно лужному середовищі (рис. 6). 


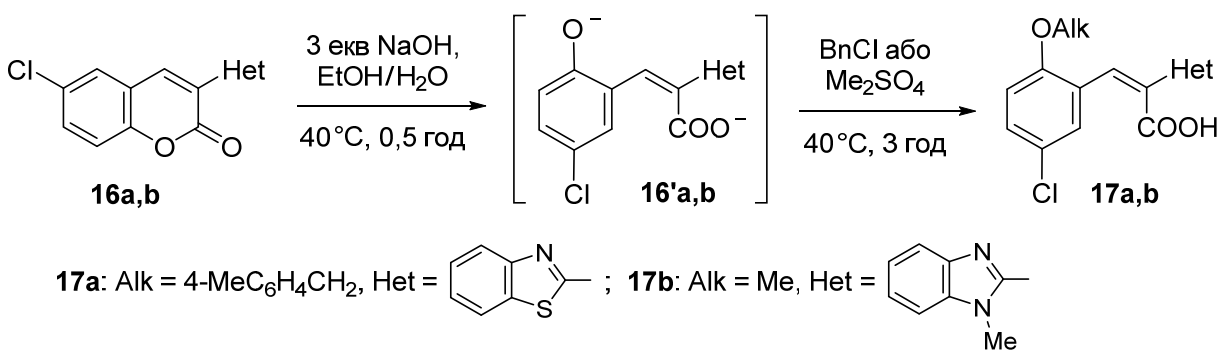

Рис. 5. Утворення о-алкокси-2-гетарилкоричних кислот 17a,b
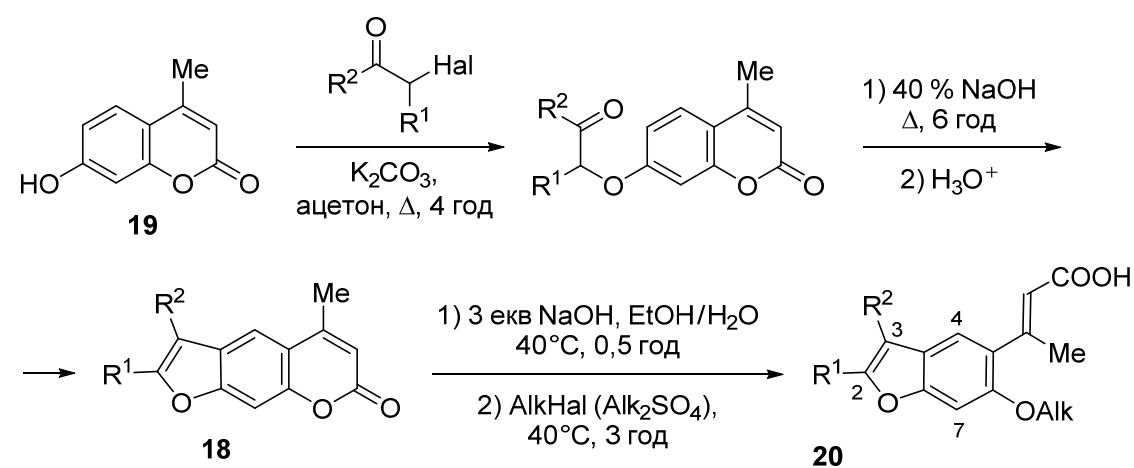

20

a: $R^{1}=H, R^{2}=A l k=M e ;$

b: $R^{1}=R^{2}=A l k=M e$

c: $\mathrm{R}^{1} \mathrm{R}^{2}=\left(\mathrm{CH}_{2}\right)_{4}, \mathrm{Alk}=\mathrm{Me}$;

d: $\mathrm{R}^{1}=\mathrm{H}, \mathrm{R}^{2}=4-\mathrm{MeOC}_{6} \mathrm{H}_{4}, \mathrm{Alk}=\mathrm{Et}$

Рис. 6. Схема синтезу 3-(3-R-6-алкоксибензофуран-5-іл)акрилових кислот із 7-гідроксикумаринів

Продуктом розкриття кумаринового циклу сполук 18a-d $є$ досить рідкісний тип акрилових кислот - із бензофурановим (кумароновим) замісником у $\beta$-положенні. У літературі наведено кілька прикладів такого перетворення [21-23], і нами було вирішено розширити ряд відомих на сьогодні кумаронілакрилових кислот і отримати їхні похідні за карбоксильною групою, щоб перевірити ефективність цієї стратегії синтезу нових похідних ряду бензофурану.

Дійсно, 3-(3-R-6-алкоксибензофуран-5-іл)акрилові кислоти 20a-d утворювались при обробці вихідних фурокумаринів диметил- та діетилсульфатом у слабколужному середовищі (рис. 6) за методикою, аналогічною синтезу похідних 17.

Після 3 год проходження реакції конверсія становила близько 60-70 \%, і збільшення тривалості перетворення та внесення надлишку алкілуючого агента не підвищували вміст цільового продукту. Тому кислоти 20 були відділені від домішок вихідної речовини шляхом розчинення у водному $\mathrm{NaHCO}_{3}$ та наступного підкислення очищеного розчину (див. розділ "Експериментальна частина"). На цьому етапі можна вилучити досить чисту вихідну речовину 18 і повторно задіяти ії̈ в алкілуванні, чим суттєво підвищити сумарний вихід сполук 20.

Після очистки кислот 20 їхня взаємодія з амінами (за стандартними методиками) не викликала труднощів, завдяки чому на основі кислоти 20b з високим виходом було отримано фенетиламід 21 із фрармакофорною сульфонамідною групою, а на основі кислоти 20a - похідну $\beta$-аланіну 22 (рис. 7).

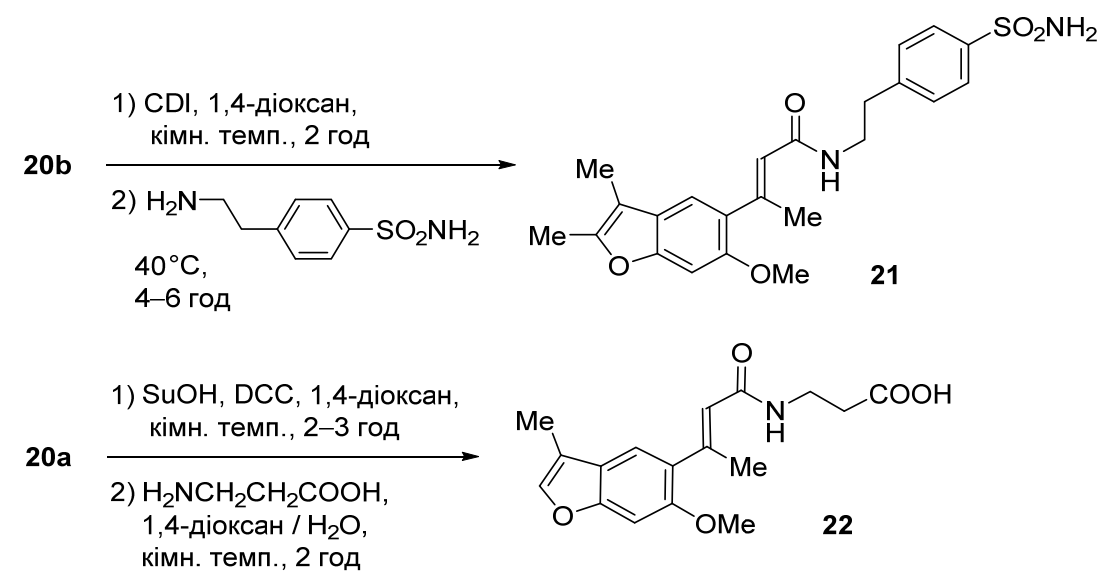

Рис. 7. Синтез амідів 3-(3-R-6-алкоксибензофуран-5-іл)акрилових кислот

У літературі ми знаходимо відомості про розкриття кумаринового циклу та алкілювання ендоциклічного атома Оксигену, що відбувається не у водному лужному середовищі, а в органічному розчиннику в присутності поташу [11, 24]. Подібне явище нами було зафіксоване лише для кумарину 23 (рис. 8) із ізокумариновим замісником у положенні 3. 
Речовину 23 було синтезовано нами раніше за допомогою реакції Пехмана із 3-(2,4-дигідроксифеніл)ізокумарину [25], після чого було проведено низку перетворень за участю реакційноздатних угрупувань. Особливістю даної речовини є її аномально низька розчинність, тому коли для метилювання ії̈ гідроксильної групи диметилсульфатом застосовували як розчинник ацетон, реакція фактично відбувалась у суспензії [25]. Це не сильно вплинуло на тривалість процесу у випадку активного алкілуючого агента $\mathrm{Me}_{2} \mathrm{SO}_{4}$, але виявилось вирішальним при переході до етилхлорацетату: відповідна моноалкоксипохідна 24 утворювалась повільно і $з$ посереднім виходом.

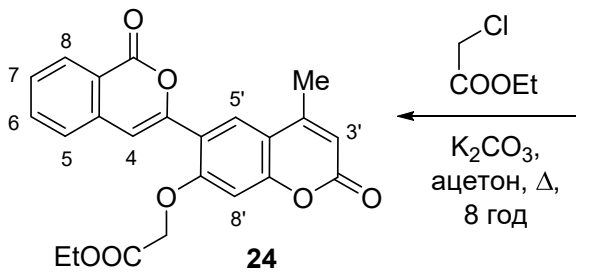<smiles>Cc1cc(=O)oc2cc(O)c(-c3cc4ccccc4c(=O)o3)cc12</smiles>

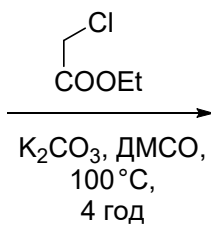<smiles>CCOC(=O)COc1cc(OCC(=O)OCC)c(-c2cc3ccccc3c(=O)o2)cc1/C(C)=C/C(=O)O</smiles>

Рис. 8. Моно- та діалкілювання 7-гідрокси-4-метил-6-(ізокумарин-3-іл)-кумарину

Спроба пришвидшити алкілювання етилхлорацетатом фенолу 23 шляхом заміни розчинника на ДМСО (в якому ця сполука розчиняється значно краще, особливо при нагріванні) дала неочікуваний для нас результат: унаслідок нагрівання при $100^{\circ} \mathrm{C}$ протягом 4 год із надлишком алкілуючого агента було отримано продукт діалкілювання 25 (рис. 8).

Таким чином, нами підтверджено, що О-алкілювання кумаринів у процесі розкриття лактонового циклу як метод одержання о-алкоксикоричних кислот має препаративну значущість для сполук із різноманітними замісниками, а також уточнено, що, залежно від характеру останніх, дане перетворення може потребувати наявності лугу і водного середовища або відбуватись при тривалому нагріванні в органічному розчиннику в присутності поташу.

Експериментальна частина. У всіх експериментах використовували реагенти вітчизняного виробництва кваліфікації "хч" або "чда", а також імпортні реагенти "analytical grade". Органічні розчинники очищено та осушено за загальноприйнятими методиками. Контроль за проходженням реакції та чистотою одержаних продуктів здійснювався методом ТШХ на платівках Merck 60 F254, елюент - $\mathrm{CHCl}_{3}-\mathrm{MeOH}, 19: 1$. Температуру плавлення визначали 3 використанням блоку Кофлера. Спектри ${ }^{1} \mathrm{H}$ ЯМР виміряні на приладі Varian 400 , робоча частота 400 МГц, розчинник - ДМСО-d6. Хімічні зсуви наведено в шкалі $\delta$ в мільйонних частках (м.ч.) відносно внутрішнього еталона - тетраметилсилану; значення КССВ (J) виміряні в герцах. Дані елементного аналізу відповідають розрахованим.

Вихідні сполуки синтезовані за методиками, наведеними в наступних джерелах: сполука 16a - [13], 16b [12], 18a - [17], 18b- [18], 18c - [19], 18d - [20], $23-$ [25].

Загальна методика синтезу 3-арилакрилових кислот 17, 20. До суспензії 5 ммоль кумарину 16 або 18 в $96 \%$ етиловому спирті (25 мл для вихідних речовин 16 або 10 мл - для сполук 18) при кімнатній температурі додають розчин 0,6 г (15 моль) $\mathrm{NaOH}$ у 25 мл води. Перемішують отриману суміш при $40^{\circ} \mathrm{C}$ протягом 0,5 год до повного розчинення. До отриманого розчину додають 7,5 моль алкілуючого агента і продовжують активно перемішувати при $40^{\circ} \mathrm{C}$ протягом 4 год. Реакційну суміш охолоджують, додають $5 \%$ соляну кислоту до $\mathrm{pH} 4$; утворений осад відфільтровують. Для очищення осад розчиняють при $40^{\circ} \mathrm{C}$ у 150 мл насиченого водного розчину $\mathrm{NaHCO}_{3}$, профрільтровують для одержання прозорого розчину. Фільтрат підкислюють $5 \%$ соляною кислотою до $\mathrm{pH} 4$, витримують 1 год при кімнатній температурі, відфільтровують осад та ретельно промивають водою.
2-(Бензо[d]тіазол-2-іл)-3-(2-((4-метилбензил)окси)5-хлорофеніл)акрилова кислота (17a). Вихід $78 \%$, т. топл. $158-160^{\circ} \mathrm{C}$. Спектр ${ }^{1} \mathrm{H}$ ЯМР, ठ, м.ч. (J, Гц): 2,29 $(3 \mathrm{H}, \mathrm{c} \mathrm{CH} 3), 5,20(2 \mathrm{H}, \mathrm{c} \mathrm{CH} 2), 7,18-7,25\left(3 \mathrm{H}, \mathrm{m}, \mathrm{H}-66^{\prime}, p-\mathrm{Tol}\right)$, $7,37(2 \mathrm{H}$, д, $J=7,7, p$-Tol), 7,45 (1H, дд, $J=8,8,2,5, \mathrm{H}-4)$, $7,48(1 \mathrm{H}$, д, $J=7,6, \mathrm{H}-3), 7,51-7,57\left(2 \mathrm{H}, \mathrm{M}, \mathrm{H}-5,5^{\prime}\right), 7,79$ $(1 \mathrm{H}, \mathrm{c},-\mathrm{CH}=), 8,02\left(1 \mathrm{H}\right.$, д, $\left.J=8,0, \mathrm{H}-4^{\prime}\right), 8,12(1 \mathrm{H}$, д, $J=$ $\left.7,9, \mathrm{H}-7^{\prime}\right)$; точне положення сигналу протону групи $\mathrm{COOH}$ не вдається встановити через обмінні процеси.

2-(1-Метил-1Н-бензо[d]імідазол-2-іл)-3-(2-метокси5-хлорофреніл)акрилова кислота (17b). Вихід $45 \%$, т. топл. $146-148^{\circ} \mathrm{C}$. Спектр ${ }^{1} \mathrm{H}$ ЯМР, $\delta$, м.ч. (J, Гц): 3,58 $\left(3 \mathrm{H}, \mathrm{c}, \mathrm{NCH}_{3}\right), 4,08\left(3 \mathrm{H}, \mathrm{c}, \mathrm{OCH}_{3}\right), 7,61(1 \mathrm{H}, \mathrm{g}, J=8,8, \mathrm{H}-$ 3), 7,75-7,78 (2H, м, H-5',6'), $7.84(1 \mathrm{H}$, дд, $J=8,8,2,0, \mathrm{H}-$ 4), 8,07 (1H, д, J = 2,0, Н-6), 8,10-8,13 (2H, м, H-4', $\left.7^{\prime}\right), 8,95$ $(1 \mathrm{H}, \mathrm{c},-\mathrm{CH}=)$; точне положення сигналу протону групи $\mathrm{COOH}$ не вдається встановити через обмінні процеси.

3-(3-Метил-6-метоксибензофуран-5-іл)бут-2-

енова кислота (20а). Вихід $67 \%$, т. топл. 166-167 ${ }^{\circ} \mathrm{C}$. Спектр ${ }^{1} \mathrm{H}$ ЯМР, ठ, м.ч. (J, Гц): 2,13 (3H, c, $\left.\mathrm{CH}_{3}\right), 2,20(3 \mathrm{H}$, $\left.\mathrm{c}, \mathrm{CH}_{3}\right), 3,81\left(3 \mathrm{H}, \mathrm{c}, \mathrm{OCH}_{3}\right), 5,87(1 \mathrm{H}, \mathrm{c},=\mathrm{CH}-\mathrm{COOH}), 7,06$ $(1 \mathrm{H}, \mathrm{c}, \mathrm{H}-7), 7,10(1 \mathrm{H}, \mathrm{c}, \mathrm{H}-4), 7,45(1 \mathrm{H}, \mathrm{c}, \mathrm{H}-2)$; точне положення сигналу протону групи $\mathrm{COOH}$ не вдається встановити через обмінні процеси.

3-(2,3-Диметил-6-метоксибензофруран-5-іл)бут-2енова кислота (20b). Вихід $61 \%$, т. топл. $159-161^{\circ} \mathrm{C}$. Спектр ${ }^{1} \mathrm{H}$ ЯМР, ठ, м.ч. (J, Гц): 2,09 (6H, м, $\left.2 \mathrm{CH}_{3}\right), 2,34$ $\left(3 \mathrm{H}, \mathrm{c}, \mathrm{CH}_{3}\right), 3,77\left(3 \mathrm{H}, \mathrm{c}, \mathrm{OCH}_{3}\right), 5,83(1 \mathrm{H}, \mathrm{c},=\mathrm{CH}-\mathrm{COOH})$, $6,96(2 \mathrm{H}, \mathrm{c}, \mathrm{H}-4,7), 11,42(1 \mathrm{H}, \mathrm{yw} . \mathrm{c}, \mathrm{COOH})$.

3-(3-Метокси-6, 7, 8, 9-тетрагідродибензо[b, d]pруран-2-іл)бут-2-енова кислота (20c). Вихід $65 \%$, т. топл. 169-170 ${ }^{\circ} \mathrm{C}$. Спектр ${ }^{1} \mathrm{H}$ ЯМР, $\delta$, м.ч.: 1,77-1,86 (2H, м, $\left.\mathrm{CH}_{2}\right), 1,87-1,96\left(2 \mathrm{H}, \mathrm{M}, \mathrm{CH}_{2}\right), 2,14\left(3 \mathrm{H}, \mathrm{c}, \mathrm{CH}_{3}\right), 2,53-2,61$ $\left(2 \mathrm{H}, \mathrm{m}, \mathrm{CH}_{2}\right), 2,67-2,73\left(2 \mathrm{H}, \mathrm{m}, \mathrm{CH}_{2}\right), 3,76\left(3 \mathrm{H}, \mathrm{c}, \mathrm{OCH}_{3}\right)$, $5,92(1 \mathrm{H}, \mathrm{c},=\mathrm{CH}-\mathrm{COOH}), 6,97(1 \mathrm{H}, \mathrm{c}, \mathrm{H}-7), 7,04(1 \mathrm{H}, \mathrm{c}, \mathrm{H}-$ 4); точне положення сигналу протону групи $\mathrm{COOH}$ не вдається встановити через обмінні процеси.

3-(6-Етокси-3-(4-метоксифеніл)бензофуран-5іл)бут-2-енова кислота (20d). Вихід 59 \%, т. топл. 187$188^{\circ} \mathrm{C}$. Спектр ${ }^{1} \mathrm{H}$ ЯМР, ठ, м.ч. (J, Гц): 1,39 (3Н, т, J = 7,2, $\left.\mathrm{OCH}_{2} \mathrm{CH}_{3}\right), 2,17\left(3 \mathrm{H}, \mathrm{c}, \mathrm{CH}_{3}\right), 3,83\left(3 \mathrm{H}, \mathrm{c}, \mathrm{OCH}_{3}\right), 4,09(2 \mathrm{H}$, KB, $\left.J=7,2, \mathrm{OCH}_{2} \mathrm{CH}_{3}\right), 5,92(1 \mathrm{H}, \mathrm{c},=\mathrm{CH}-\mathrm{COOH}), 7,01(2 \mathrm{H}$, д, $\left.J=8,4,2 \mathrm{H}_{\mathrm{Ar}}\right), 7,15(1 \mathrm{H}, \mathrm{c}, \mathrm{H}-7), 7,39(1 \mathrm{H}, \mathrm{c}, \mathrm{H}-4), 7,56$ $\left(2 \mathrm{H}\right.$, д, $\left.J=8,4,2 \mathrm{H}_{\mathrm{Ar}}\right), 7,94(1 \mathrm{H}, \mathrm{c}, \mathrm{H}-2), 11,43(1 \mathrm{H}$, уш. c, $\mathrm{COOH})$.

3-(2,3-Диметил-6-метоксибензофуран-5-іл)-N-(4сульфрамоїлфренетил)бут-2-енамід 21. Розчиняють 0,39 г (1,5 ммоль) кислоти 2b та 0,29 г (1,8 ммоль) карбонілдіімідазолу у 10 мл сухого діоксану та перемішують отриманий розчин при кімнатній температурі протягом 
2 год. Після цього додають 0,36 г (1,8 ммоль) 4-(2-аміноетил)бензенсульфаміду та перемішують при $40^{\circ} \mathrm{C}$ ще 46 год до завершення реакції (контроль - ТШХ). Реакційну суміш виливають у 50 мл води, осад відфільтровують та перекристалізовують із ізопропілового спирту. Вихід 86 \%, т. топл. $178-179^{\circ} \mathrm{C}$. Спектр ${ }^{1} \mathrm{H}$ ЯМР, ठ, м.ч. (J, Гц): 2,01 $\left(3 \mathrm{H}, \mathrm{c}, \mathrm{CH}_{3}\right), 2,06\left(3 \mathrm{H}, \mathrm{c}, \mathrm{CH}_{3}\right), 2,33\left(3 \mathrm{H}, \mathrm{c}, \mathrm{CH}_{3}\right), 2,64(2 \mathrm{H}$, $\left.\mathrm{T}, \mathrm{J}=7,0, \mathrm{NHCH}_{2} \mathrm{CH}_{2}\right), 3,17\left(2 \mathrm{H}\right.$, тд, J = 7,0, 6,5, $\left.\mathrm{NHCH}_{2} \mathrm{CH}_{2}\right)$, $3,71\left(3 \mathrm{H}, \mathrm{c}, \mathrm{OCH}_{3}\right), 5,90(1 \mathrm{H}, \mathrm{c},=\mathrm{CH}-\mathrm{COOH}), 7,01(1 \mathrm{H}, \mathrm{c}, \mathrm{H}-$ 7), 7,06 (1H, c, H-4), 7,28 (4H, M, $\left.2 \mathrm{H}_{\mathrm{Ar}}, \mathrm{NH}_{2}\right), 7,56(1 \mathrm{H}, \mathrm{T}$, $\mathrm{J}=6,5, \mathrm{NH}), 7,70\left(2 \mathrm{H}, \mathrm{A}, J=8,0,2 \mathrm{H}_{\mathrm{Ar}}\right)$

3-(3-(3-Метил-6-метоксибензофуран-5-іл)бут-2енамідо)пропанова кислота 22. До розчину 0,37 г (1,5 ммоль) кислоти 20а та 0,20 г (1,65 ммоль) $N$-гідроксисукциніміду в 15 мл абсолютного діоксану за кімнатної температури та при інтенсивному перемішуванні додають 0,35 г (1,65 ммоль) дициклогексилкарбодііміду. Реакційну суміш перемішують за кімнатної температури 23 год (контроль проходження реакції здійснюють методом ТШХ); після чого до утвореного активованого естеру додають розчин 0,15 г (1,65 ммоль) $\beta$-аланіну та 0,21 г $\mathrm{NaHCO}_{3}$ в 15 мл води. Реакційну суміш перемішують за кімнатної температури 2 год, контролюючи завершення реакції за допомогою ТШХ. Осад дициклогексилсечовини відфільтровують, фрільтрат виливають у 100 мл води та додають розведену соляну кислоту до слабкокислої реакції. Утворений осад відфрільтровують та перекристалізовують із ізопропілового спирту. Вихід $52 \%$, т. топл. $145-146^{\circ} \mathrm{C}$. Спектр ${ }^{1} \mathrm{H}$ ЯМР, $\delta$, м.ч. (J, Гц): 2,05 $\left(3 \mathrm{H}, \mathrm{c}, \mathrm{CH}_{3}\right), 2,18\left(5 \mathrm{H}\right.$, yш. c, $\left.\mathrm{CH}_{3}, \mathrm{NHCH}_{2} \mathrm{CH}_{2}\right), 3,12(2 \mathrm{H}$, дт, J = 6,5, 6,0, $\left.\mathrm{NHCH}_{2} \mathrm{CH}_{2}\right), 5,89(1 \mathrm{H}, \mathrm{c},=\underline{\mathrm{CH}}-\mathrm{COOH}), 7,03$ $(1 \mathrm{H}, \mathrm{c}, \mathrm{H}-7), 7,06(1 \mathrm{H}, \mathrm{c}, \mathrm{H}-4), 7,27(1 \mathrm{H}, \mathrm{yш} . \mathrm{T}, \mathrm{J}=6,5, \mathrm{NH})$, $7,45(1 \mathrm{H}, \mathrm{c}, \mathrm{H}-2)$; точне положення сигналу протону групи $\mathrm{COOH}$ не вдається встановити через обмінні процеси.

Етиловий естер 2-((4-метил-2-оксо-6-(1-оксо-1Нізохромен-3-іл)-2Н-хромен-7-іл)окси)оцтової кислоти (24). Кип'ятять при активному перемішуванні суспензію 0,24 г (0,75 ммоль) сполуки 23, 0,16 мл (1,5 ммоль) етилхлорацетату та 0,42 г (3 ммоль) свіжопрокаленого дрібно розтертого поташу в 40 мл сухого ацетону протягом 8 год. До реакційної суміші додають 100 мл води, осад відфільтровують, промивають водою та перекристалізовують із ДМФА. Вихід $72 \%$, т. топл. $276-277^{\circ} \mathrm{C}$. Спектр ${ }^{1} \mathrm{H}$ ЯМР, $\delta$, м.ч. (J, Гц): $1,33\left(3 \mathrm{H}, \mathrm{T}, J=6,4, \mathrm{COOCH}_{2} \mathrm{CH}_{3}\right)$, $2,50\left(3 \mathrm{H}, \mathrm{c}, 4-\mathrm{CH}_{3}\right), 4,30\left(2 \mathrm{H}, \mathrm{KB}, J=6,4, \mathrm{COOCH}_{2} \mathrm{CH}_{3}\right)$, $5,00\left(2 \mathrm{H}, \mathrm{c}, \mathrm{OCH}_{2} \mathrm{COOEt}\right), 6,21\left(1 \mathrm{H}, \mathrm{c}, \mathrm{H}-3^{\prime}\right), 7,18(1 \mathrm{H}, \mathrm{c}$, H-8'), 7,55 (1H, т, J = 7,6, H-7), 7,60 (1H, д, J = 7,6, H-5), $7,79(1 \mathrm{H}, \mathrm{T}, J=7,6, \mathrm{H}-6), 7,83(1 \mathrm{H}, \mathrm{c}, \mathrm{H}-4), 8,13(1 \mathrm{H}, \mathrm{c}, \mathrm{H}-$ $\left.5^{\prime}\right), 8,18(1 \mathrm{H}$, д, $J=7,6, \mathrm{H}-8)$.

3-(2,4-Біс(2-етокси-2-оксоетокси)-5-(1-оксо-1Н-ізохромен-3-іл)феніл)бут-2-енова кислота (25). Нагрівають при $100^{\circ} \mathrm{C}$ та активному перемішуванні суспензію 0,24 г (0,75 ммоль) сполуки 23, 0,32 мл (3 ммоль) етилхлорацетату та 0,84 г (6 ммоль) свіжопрокаленого дрібно розтертого поташу в 20 мл ДМСО протягом 4 год. До реакційної суміші додають 100 мл води та розведену со- ляну кислоту до слабкокислої реакції, осад відфільтровують, промивають водою та перекристалізовують із ДМФА. Вихід $57 \%$, т. топл. $205^{\circ} \mathrm{C}$ розкл. Спектр ${ }^{1} \mathrm{H}$ ЯМР, $\delta$, м.ч. $\left(J\right.$, Гц): $1,13\left(3 \mathrm{H}, \mathrm{T}, J=6,8, \mathrm{COOCH}_{2} \mathrm{CH}_{3}\right), 1,35(3 \mathrm{H}$, $\left.\mathrm{T}, J=6,8, \mathrm{COOCH}_{2} \mathrm{CH}_{3}\right), 2,32\left(3 \mathrm{H}, \mathrm{c}, 4-\mathrm{CH}_{3}\right), 4,20(2 \mathrm{H}, \mathrm{KB}$, $\left.J=6,8, \mathrm{COOCH}_{2} \mathrm{CH}_{3}\right), 4,36\left(2 \mathrm{H}, \mathrm{kB}, J=6,8, \mathrm{COOCH}_{2} \mathrm{CH}_{3}\right)$, 4,87 (2H, c, $\left.\overline{\mathrm{OCH}}_{2} \mathrm{COOEt}\right), 5,02\left(2 \mathrm{H}, \mathrm{c}, \mathrm{OCH}_{2} \mathrm{COOEt}\right), 6,21$ $(1 \mathrm{H}, \mathrm{c},-\mathrm{CH}=), 7,17(1 \mathrm{H}, \mathrm{g}, J=7,6, \mathrm{H}-5), 7,36(1 \mathrm{H}, \mathrm{T}, J=7,6$, $\mathrm{H}-7), 7,43(1 \mathrm{H}, \mathrm{T}, J=7,6, \mathrm{H}-6), 7,60\left(1 \mathrm{H}, \mathrm{c}, \mathrm{H}-3^{\prime}\right), 7,75(1 \mathrm{H}$, с, $\left.\mathrm{H}_{-6}{ }^{\prime}\right), 7,97(1 \mathrm{H}$, д, $\mathrm{J}=7,6, \mathrm{H}-8)$; точне положення сигналу протону групи СООН не вдається встановити через обмінні процеси.

Список використаних джерел

1. Buckingham J., Munasinghe V. R. N. Dictionary of Flavonoids. CRC Press, Taylor \& Francis Group. 2015. 1031

2. The Flavonoids: advances in research since 1986. Edited by J. B. Harborne. 1st ed. Springer Science+Business Media Dordrecht, 1994. 676

3. Heravi M. M., Khaghaninejad S., Mostofi M. Pechmann Reaction in the Synthesis of Coumarin Derivatives. In: Advances in Heterocyclic Chemistry. Edited by A. Katritzky. Academic Press, 2014, Vol. 112. Chapt. 1, 1st ed. 1-50.

4. Moskvina V. S., Khilya V. P. Chem. Nat. Compd. 2019 55, 401-427.

5. Хиля В. П., Шаблыкина О. В., Ищенко В. В. Химия гетероциклических соединений. Современные аспекты / ред. В. Г. Карцев. М. : IBS Press, 2003. 2, 518-533.

Khilya V. P., Shablykina O. V., Ishchenko V. V. Chemistry of Heterocyclic Compounds. Modern Aspects / ed. V. G. Kartsev. Moscow : IBS Press, 2003. 2. 518-533 (in Russian).

6. Kolichala N., Thummala B., Karkala V. K. P. J. Heterocycl. Chem. 2018. 55 (6). 1398-1402.

7. Hagen V., Bendig J., Frings S., Eckardt T., Helm S., Reuter D., Kaupp U. B. Angew. Chem. Int. Ed. 2001. 40(6). 1046-1048.

8. Perkin W. J. Chem. Soc. 1877. 31. 388-427.

9. Welter T.R. (Eastman Kodak Company). Patent US4720559. 1988.

10. Farooq S., Shakeel-U-Rehman, Hussain A., Hamid A., Koula S. Eur. J. Med. Chem. 2014. 84 (C). 545-554.

11. Huang C.-Y., Chen C.-N., Huang W.-J., Lin C.-W., Huang J.-S., Chi L.L., Chen A.-L., Lee C.-Y., Huang Y.-C. (Naturewise Biotech \& Medicals). Patent US2010256401. 2010.

12. Khilya O. V., Frasinyuk M. S., Turov A. V., Khilya V. P. Chem. Heterocycl. Compd. 2001. 37 (8). 1029-1037

13. Khilya O. V., Shablykina O. V., Frasinyuk M. S., Turov A. V., Ishchenko V. V., Khilya V. P. Chem. Heterocycl. Compd. 2004. 40 (11). $1408-1420$

14. Shablykina O. V., Khilya O. V., Ishchenko V. V., Khilya V. P. Chem. Nat. Compd. 2005. 41(5). 529-532.

15. Kopylova T. N., Samsonova L. G., Gadirov R. M., Shablykina O. V., Khilya V. P., Ishchenko V. V. Opt. Spectrosc. 2006. 100(1). 34-40.

16. Шабликіна О. Козловська Х., Кузів С., Іщенко В., Хиля В Вісн. Київ. нац. ун-ту імені Тараса Шевченка. Хімія. 2017.53 (1). 9-12.

Shablykina O., Kozlovska K., Kuziv S., Ishchenko V., Khilya V. Visnyk Kyyivs'koho natsional'noho universytetu imeni Tarasa Shevchenka. Khimiya. 2017. 53 (1). 9-12.

17. Patel J. M., Soman S. S. J. Heterocycl. Chem. 2010. 47(2). 379-383.

18. Elgogary S. R., Hashem N. M., Khodeir M. N. J. Heterocycl. Chem. 2015. 52(2). 506-512

19. Santana L., Uriarte E., Gonzalez-Diaz H., Zagotto G., Soto-Otero R., Mendez-Alvarez E. J. Med. Chem. 2006. 49(3). 1149-1156.

20. Koerner P. Arch. Pharm. 2002. 335(5). 187-199.

21. Jois H. S., Manjunath B. L. Chem. Ber. 1937. 70(3). 434-437.

22. Kaul S. K., Sehgal C. K., Taneja S. C., Dhar K. L., Atal C. K. Ind. J. Chem., Sect. B. 1982. 21(5). 472-474.

23. Mandour A. H., Fawzy N. M., El-Shihi T. H., El-Bazza Z. E. Pakistan J. Sci. Industr. Res. 1995. 38 (11-12). 402-406.

24. Marumoto S., Miyazawa M. Bioorg. Med. Chem. 2012. 20 (2). 784-788.

25. Шабликіна О. В., Іщенко В. В., Нагорна З. В., Хиля В. П. Доповіді НАН України. 2017. (2). 67-71.

Shablykina O. V., Ishchenko V. V., Nagornaya Z. V., Khilya V. P. Dopov. Nac. akad. nauk Ukr. 2017. (2). 67-71.

Надійшла до редколегії 13.09.19

С. Шилин, канд. хим. наук,

О. Шаблыкина, канд. хим. наук, shablykina@ukr.net

Киевский национальный университет имени Тараса Шевченко, Киев, Украина

О. Шаблыкин, канд. хим. наук,

Институт биоорганической химии и нефтехимии им. В. П. Кухаря НАН Украины, Киев, Украина

В. Хиля, д-р хим. наук, чл.-кор. НАН Украины,

3. Нагорная, студ.,

Киевский национальный университет имени Тараса Шевченко, Киев, Украина

ЧАСТНЫЕ СЛУЧАИ ОБРАЗОВАНИЯ О-АЛКОКСИКОРИЧНЫХ КИСЛОТ НА ОСНОВЕ КУМАРИНОВ В УСЛОВИЯХ О-АЛКИЛИРОВАНИЯ

На основе кумаринов разнообразного строения путем раскрытия лактонного фрагмента и О-алкилирования фенольного фрагмента получен ряд новых производных о-алкоксикоричных кислот. Данное превращение в случае 3-азолилзамещенных кумаринов и фуро[3,2-g]кумаринов было проведено в водной щелочной среде, а в случае 7-гидрокси-4-метил-6-(изокумарин-3-ил)кумарина - при нагревании в ДМСО в присутствии поташа.

Ключевые слова: кумарин, О-алкилирование, о-алкоксикоричная кислота. 
S. Shilin, PhD,

O. Shablykina, PhD,

shablykina@ukr.net,

Taras Shevchenko National University of Kyiv, Kyiv, Ukraine

O. Shablykin, PhD,

V. P. Kukhar Institute of Bioorganic Chemistry and Petrochemistry of the NAS of Ukraine, Kyiv, Ukraine

V. Khilya, Dr. Sci., Corresponding Member of the NAS of Ukraine,

Z. Nagorna, stud.,

Taras Shevchenko National University of Kyiv, Kyiv, Ukraine

\section{CERTAIN CASES OF O-ALKOXYCINNAMIC ACIDS CREATION FROM COUMARINS IN O-ALKYLATION CONDITION}

A number of new derivatives of o-alkoxy cinnamic acids were obtained from various coumarins by opening the lactone fragment and 0 -alkylation of the endocyclic Oxygen atom.

The $\alpha$-hetaryl- $\beta$-(2-alkoxy-5-chlorophenyl)cinnamic acids were obtained from 3-(benzothiazol-2-yl)-6-chlorocoumarin and 3-(benzimidazol-2-yl)-6chlorocoumarin by treatment with diluted alkali followed by p-methylbenzyl chloride or dimethyl sulfate addition, respectively.

A similar reaction stages (opening in aqueous alkali and alkylation of the phenolate anion) was applied to the synthetic analogues of psoralen 5-methylfuro[3,2-g]coumarins with various substituents in the furan fragment. Thus it was possible to obtain a number of 3- and 4-substituted 3-(6alkoxybenzofuran-5-yl)but-2-enoic acids. But in this case, the conversion of the starting furo[3,2-g]coumarins to cinnamic acid derivatives was not complete even after long time of reaction with a big excess of an alkylation agent. Therefore, the necessary step is the separation of the target acid from unreacted coumarin by dissolving the product in a saturated $\mathrm{NaHCO}_{3}$ solution. The insoluble part is a practically pure starting material, which can be recycled in the reaction; so the total yield of the product would be increased. To demonstrate the synthetic abilities of 3-(6-alkoxybenzofuran5-yl)but-2-enoic acids these compounds were used in synthesis of amides with pharmacophore fragments: a phenethylamine derivative with an additional sulfamide group and a $\beta$-alanine derivative.

The experiments showed that the 3-azolylcoumarins and furo[3,2-g]coumarins coumarin cycle's opening occurs only in aqueous alkali, and when alkylated in an organic solvent in the presence of $\mathrm{K}_{2} \mathrm{CO}_{3}$, the lactone fragment remains unchanged. The 7-hydroxy-6-(isocoumarin-3-yl)-4methylcoumarin cycle turned out to be more labile. The result of alkylation of this compound with ethyl acetate of chloroacetic acid in the presence of $\mathrm{K}_{2} \mathrm{CO}_{3}$ depended on the nature of the aprotic solvent and the temperature of reaction. So, when this reaction was carried out in boiling acetone, only the free hydroxyl group at position 7 of coumarin was alkylated. But when the initial coumarin was heated at $100{ }^{\circ} \mathrm{C}$ with an excess of an alkylating agent in DMSO, simultaneous alkylation of both the free 7-OH group and the endocyclic Oxygen atom occurred.

Keywords: coumarin, alkylation, o-alkoxycinnamic acid.

УДК 678.621.315.772.93

DOI: https://doi.org/10.17721/1728-2209.2019.1(56).7

Н. Давиденко, д-р физ.-мат. наук, И. Давиденко, д-р физ.-мат. наук, Киевский национальный университет имени Тараса Шевченко, Киев, Украина

В. Кравченко, д-р хим. наук, Институт физико-органической химии и углехимии им. Л. М. Литвиненко НАН Украины, Киев, Украина

Е. Мокринская, канд. хим. наук, mokrinskaya@ukr.net, В. Павлов, вед. инж.,

С. Студзинский, канд. хим. наук, В. Тарасенко, инж. 1 кат.,

Л. Тонкопиева, канд. хим. наук,

Киевский национальный университет имени Тараса Шевченко, Киев, Украина

\section{ВЛИЯНИЕ ПРИРОДЫ ЗАМЕСТИТЕЛЯ В АЗОБЕНЗОЛЬНЫХ ХРОМОФОРАХ НА ДИФРАКЦИОННУЮ ЭФФЕКТИВНОСТЬ ПОЛЯРИЗАЦИОННЫХ ГОЛОГРАММ}

На основе пленок сополимера стирола с нонилметакрилатом и добавками азобензольных красителей с различными акцепторными заместителями созданы регистрирующие среды для поляризационной голографии и исследованы их фотоэлектрофизические и информационные свойства. Обнаружено, что при изменении взаимной ориентации записываюцих лучей от ортогональной к параллельной дифракционная эффективность голограмм увеличивается в случае использования азокрасителя с заместители в орто- и пара-положении по отношению к азогруппе. Обнаруженный эффект зависимости дифракционной эффективности от строения хромофоров связывается с углублением цвета красителя.

Ключевые слова: азобензольные красители, электроноакцепторные заместители, поляризационная голография, регистрирующие среды, дифракционная эффективность.

Введение. Пленки полимерных композитов (ППК) с добавками азокрасителей или содержащие химически связанные с основной полимерной цепью азобензольные группы проявляют фотоактивные свойства [1-3] и их можно использовать для создания электрооптических модуляторов [4] света и регистрирующих сред (РС) для поляризационной голографиии [5-7]. Под действием линейно поляризованного света в этих пленках появляется фотоиндуцированная оптическая анизотропия (ФОА), которая вызвана процессами транс-цис-изомеризации азобензольных групп. Этот эффрект позволяет использовать рассматриваемые композиты в качестве РС для поляризационной голографиии. Дифракционная эффективность (ДЭ) получаемых поляризационных голограмм существенно зависит от состава РС. Большое значение имеет количество введенного в матрицу азокрасителя, его структура и интенсивность окраски. В данной работе рассмотрено влияние различных акцепторных заместителей в азокрасителе на ДЭ поляризационных голограмм, регистрируемых в РС, содержащих такие красители.

( С Давиденко Н., Давиденко И., Кравченко В., Мокринская Е., Павлов В., Студзинский С., Тарасенко В., Тонкопиева Л., 2019 дований нами синтезированы азокрасители следующего строения:<smiles>Cc1cc(N=Nc2ccc([N+](=O)[O-])cc2)ccc1O</smiles><smiles>O=[N+]([O-])c1ccc(/N=N/c2ccc(O)cc2)c(Br)c1</smiles>

4-(2-бром-4- нитрофенилазо)фенол (3)
Материалы и методика исследований. Для иссле- 